\title{
Behaviour of Strengthened RC Frames with Eccentric Steel Braced Frames
}

\author{
Mehmet Kamanli ${ }^{1, *}$, and Alptug Unal ${ }^{1}$ \\ ${ }^{1}$ Selcuk University, Engineering Faculty, Civil Engineering Department, Konya, Turkey
}

\begin{abstract}
After devastating earthquakes in recent years, strengthening of reinforced concrete buildings became an important research topic. Reinforced concrete buildings can be strengthened by steel braced frames. These steel braced frames may be made of concentrically or eccentrically indicated in Turkish Earthquake Code 2007. In this study pushover analysis of the 1/3 scaled 1 reinforced concrete frame and 1/3 scaled 4 strengthened reinforced concrete frames with internal eccentric steel braced frames were conducted by SAP2000 program. According to the results of the analyses conducted, load-displacement curves of the specimens were compared and evaluated. Adding eccentric steel braces to the bare frame decreased the story drift, and significantly increased strength, stiffness and energy dissipation capacity. In this strengthening method lateral load carrying capacity, stiffness and dissipated energy of the structure can be increased.
\end{abstract}

\section{Introduction}

There are a lot of studies about strengthening of Reinforced Concrete (RC) buildings, but no adequate detailed studies conducted for this subject. Reinforced concrete buildings can be strengthened by steel braced frames. These steel braced frames may be made of concentrically or eccentrically indicated in Turkish Earthquake Code 2007 (Fig. 1).

Such systems are generally used in order to supply stiffness and strength against lateral loads in low and medium height buildings. In addition to saving of material in these systems, it is possible to restrain storey drift effectively by providing high lateral stiffness. The braced frames provide energy consumption under the effect of big lateral loadings with changing direction by pressure-wrenching and by flowing under tensile loads $[1,2]$. Also there are some analytical and experimental studies related to concentrically and eccentrically steel braced frames in the literature [3-14].

In this study pushover analysis of the $1 / 3$ scaled 1 reinforced concrete frame and $1 / 3$ scaled 4 strengthened reinforced concrete frames with internal eccentrically steel braced frames were conducted by SAP2000 program. In the study, Eccentrically Steel Braced Frames (ESBF) described in Turkish Earthquake Code 2007 were designed and tested with pushover analyses, which are 4 types in total being $\mathrm{V}$ - braced, $\Lambda$ - braced, $\backslash$ - braced and /- braced. For this purpose, 4 pieces of $1 / 3$ scaled strengthened RC frames with ESBF models made up of $60 \times 60 \times 4 \mathrm{~mm}$ cross-section box profile were formed. In the analytic study, pushover analyses of the RC frames strengthened with these ESBFs were conducted by the SAP2000 program, and according to the results of the analyses conducted, load-displacement curves of the specimens were given and compared.
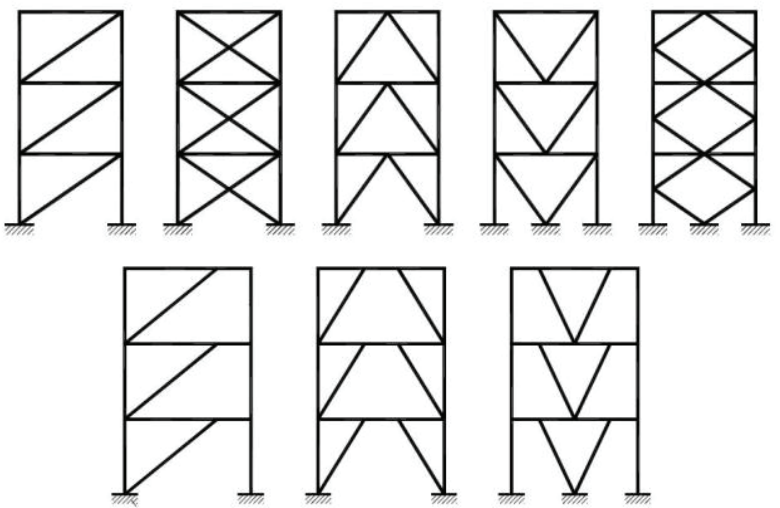

Fig. 1. Steel Braced Frames.

\section{Material and Methods}

In building systems formed in order to represent the buildings in literature, the buildings were modelled by generally forming $1 / 3$ scaled systems. The cross-sections in $1 / 3$ scaled ESBF group were determined as $60 \times 60 \times 4$ $\mathrm{mm}$. ESBFs can be used to meet lateral loads in current building systems, to limit storey drifts and to improve stiffness of the building as well as they can be added to the system as reinforcement elements afterwards. For this purpose, it was considered to strengthen $1 / 3$ scaled reinforced concrete frame with designed $1 / 3$ scaled ESBFs by means of transverse beam. In Fig. 2, dimensions of empty reinforced concrete frame were given. In the bare frame the concrete compressive strength is taken as $20 \mathrm{MPa}$, reinforcing yield strength is

* Corresponding author: mkamanli@selcuk.edu.tr 
taken as $420 \mathrm{MPa}$ and reinforcing tensile strength is taken as $550 \mathrm{MPa}$. The columns in experiment members were dimensioned as $100 \times 150 \mathrm{~mm}$ and the beams were dimensioned as $150 \times 150 \mathrm{~mm}$. The dimensions of groundwork were selected as quite big to prevent any damage occurrence during experiment.

In the foundations, $3 \phi 14 \mathrm{~mm}$ ( 3 rebar and rebar diameter $=14 \mathrm{~mm}$ ) reinforcement in the top, $3 \phi 14 \mathrm{~mm}$ reinforcement in the bottom and $2 \phi 14 \mathrm{~mm}$ web reinforcement were used. The stirrups were arranged as $\phi 8 / 100 \mathrm{~mm}$ in the foundation. Column longitudinal reinforcement was prepared as $4 \phi 10 \mathrm{~mm}$ and $\phi 6 / 100 \mathrm{~mm}$ stirrup was used. Confinement zone was not formed in columns and the stirrups were not continued at the connection zones of foundation and beams. In the beams, $3 \phi 10 \mathrm{~mm}$ reinforcement at the top, $3 \phi 10 \mathrm{~mm}$ longitudinal and $\phi 6 / 100 \mathrm{~mm}$ lateral reinforcements at the bottom were used. The stirrups were not continued in the zones where beams enter to the columns and stirrup compaction was not performed at the places close to connection zones.

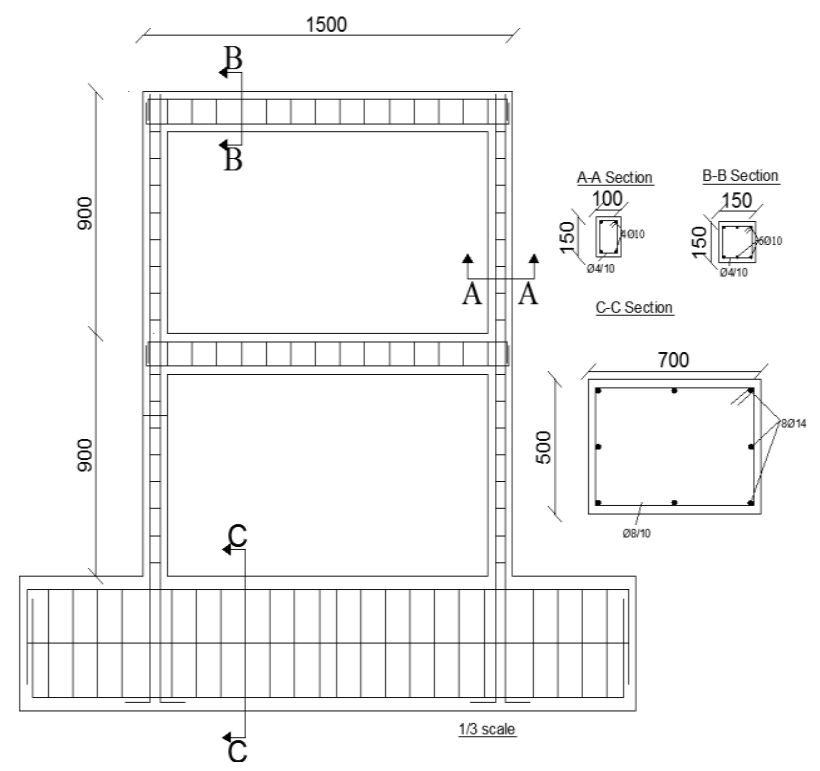

Fig. 2. 1/3 scaled base reinforced concrete frame.

In order to investigate the strength properties of concentric steel braced frame specimen, steel extrusion experiment was carried out according to TS EN ISO 6892-1st of January 2010 standard and its results were investigated [15].

According to test results, it was determined that maximum load in the cross section was $20.5 \mathrm{kN}$, tensile stress was $400.2 \mathrm{~N} / \mathrm{mm}^{2}$, yield strength was 337.9 $\mathrm{N} / \mathrm{mm}^{2}$ and elongation at rupture was $29.1 \%$.

In this study, pushover analysis of $1 / 3$ scaled reinforced concrete frame with inadequate earthquake resistance and 5 reinforced concrete frames reinforced with CSBF were carried out with SAP2000 program (Fig. 3) [16,17]. In pushover analysis performed with SAP2000 program, FEMA 356 American Regulations were applied. It is necessary to make different definitions for these columns, beams and braced.

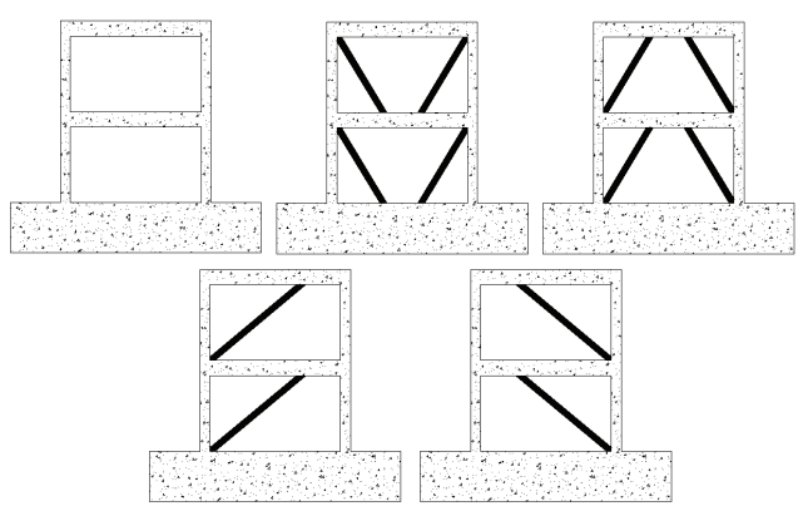

Fig. 3. Specimens.

The length of plastic hinge was taken as $L p=0.5 \mathrm{~h}$ in FEMA 356 and TEC-2007. In SAP2000 program, the hinge choices for column, beam and braced were presented. P-M3, M3 and P hinge definitions were given for steel columns, steel beams and steel braced, respectively. Moreover, moment curvature value was calculated for reinforced concrete frame and it was defined in SAP2000 [16-19]. Moment curvature graphs for reinforced concrete frame are given in Fig. 5.

SAP2000 implements the plastic hinge properties described in FEMA-356. As shown in Fig. 4, five points labeled as $\mathrm{A}, \mathrm{B}, \mathrm{C}, \mathrm{D}$, and $\mathrm{E}$ define the forcedeformation behavior of a plastic hinge.

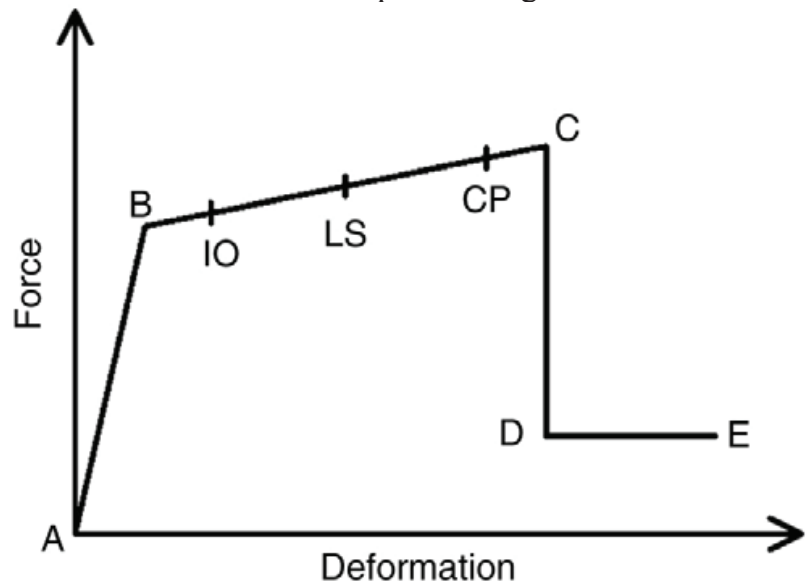

Fig. 4. Force-deformation relationship of a typical plastic hinge.

The values assigned to each of these points vary depending on the type of element, material properties, longitudinal and transverse steel content, and the axial load level on the element [18].

Immediate Occupancy (IO) - yielding of steel, significant cracking of concrete and nonstructural damage will arises.

Life Safety (LS) - damage of structural and nonstructural components will starts. We have to make essential circulation routes accessible to minimize risk of injury and causality for this stage.

Collapse Prevention (CP) - This point ensure a small risk of partial or complete building collapse by limiting 
structural deformations and forces to the onset of significant strength and stiffness degradation.

Point $\mathrm{C}$ is the indication of ultimate capacity of the structure and Point D indicate residual strength for the structure. Complete failure will occur at point E.

In TEC-2007, Immediate Occupancy (IO) limit is given as $(\varepsilon c u) M N=0.0035$, Life Safety (LS) limit is given as

( $\varepsilon \mathrm{cg}) \mathrm{GV}=0.0135$ and Collapse Prevention (CP) limit is indicated as $(\varepsilon \mathrm{cg}) \mathrm{GC}=0.018$ and pushover analysis was carried out with SAP2000 program based on these data.

Since equivalent seismic load was considered in pushover analysis and the weights of upper and ground storey were equal, 2 units of lateral loads were defined for upper storey and 1 unit of lateral load was defined for ground storey.

\section{Results and Discussion}

In this part, the results of analytical studies are presented and compared.
Moment-curvature and PM Interaction relationship for reinforced concrete frame are presented in Fig. 5.

A meaning of the specimens were given below:

RS: Reference Specimen (Bare Reinforced Concrete Frame)

VBS: V-Braced Specimen (Strengthened by Eccentrically Steel V-Braced Specimen)

TVBS: Transverse V-Braced Specimen (Strengthened by Eccentrically Steel Transverse V-Braced Specimen)

DBS: /-Braced Specimen (Strengthened by Eccentrically Steel Diagonal-Braced Specimen)

TDBS:-Braced Specimen (Strengthened by Eccentrically Steel Transverse Diagonal-Braced Specimen)

Base shear-top displacement graphs obtained after pushover analysis of RS, VBS, TVBS, DBS and TDBS types are given in Fig. 6. In Table 1, on the other hand, maximum load and top displacement values for each specimen were given. According to these data and graphs, it was observed that TVBS type had more loadcarrying capacity than the other types.
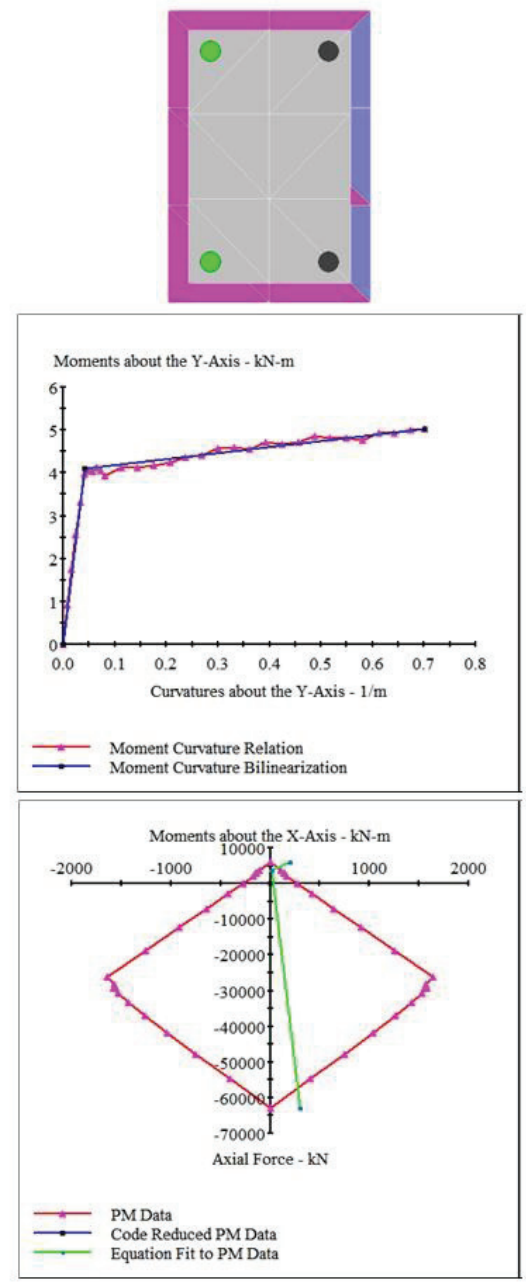

(a)
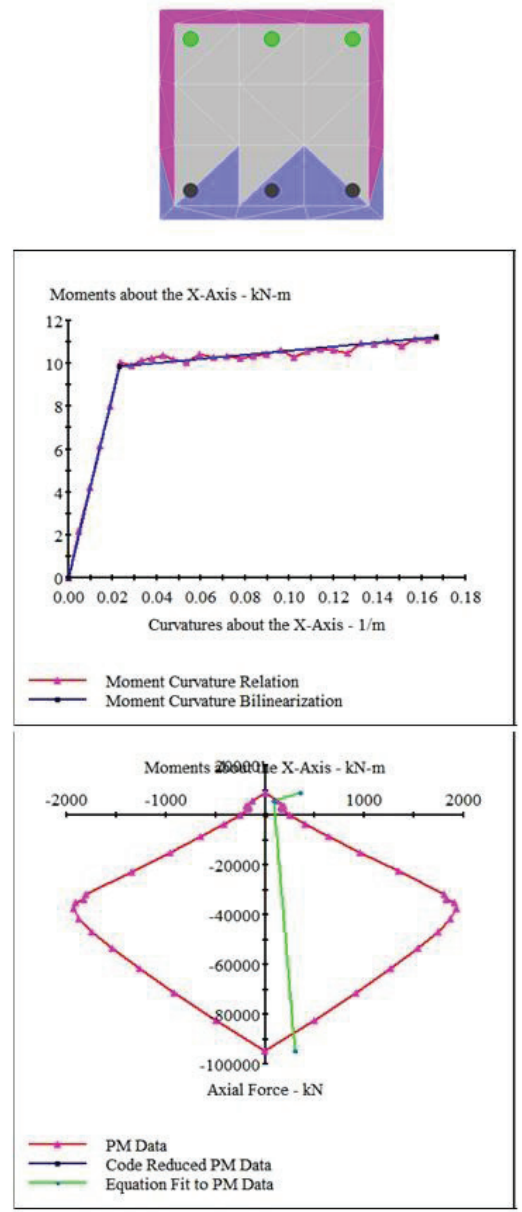

(b)

Fig. 5. Moment-curvature and PM Interaction relationship for reinforced concrete frame (a) column (b) beam. 


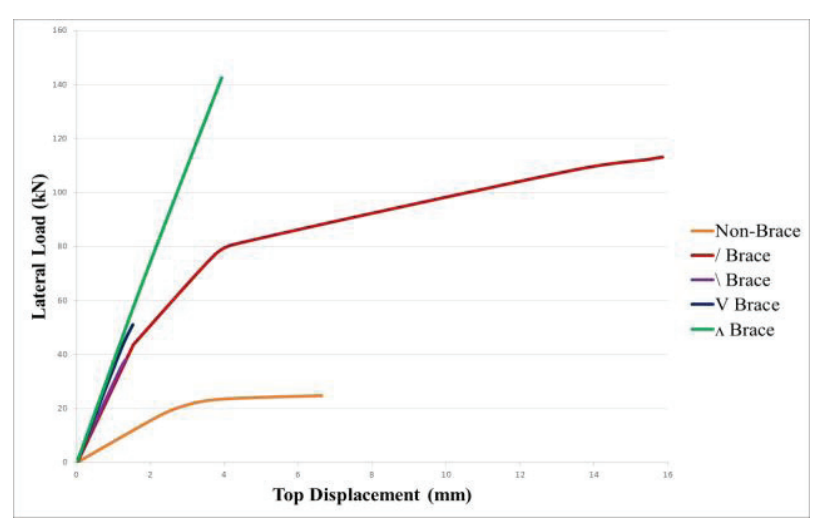

Fig. 6. Lateral load-carrying capacities of specimens

Table 1. Maximum load and top displacement values for each specimen.

\begin{tabular}{|c|c|c|c|c|c|}
\cline { 2 - 6 } \multicolumn{1}{c|}{} & RS & VBS & TVBS & DBS & TDBS \\
\hline $\begin{array}{c}\text { Max. Load } \\
(\mathbf{k N})\end{array}$ & 24.87 & 51.19 & 142.51 & 113.03 & 38.26 \\
\hline $\begin{array}{c}\text { Max. } \\
\text { Displacement } \\
(\mathbf{m m})\end{array}$ & 0.66 & 0.15 & 0.39 & 1.59 & 0.14 \\
\hline
\end{tabular}

\section{Conclusions}

Lateral load-carrying capacities are ordered in descending order as TVBS, DBS, VBS, TDBS and RS. Lateral load carrying capacity of strengthened frames to the lateral load carrying capacity of the bare frame varied between 1.54 to 5.73. The largest strength increase was obtained in TVBS. Lateral strength of VBS was 2.06 times, TVBS was 5.73 times, DBS was 4.54 times and TDBS was 1.54 times greater than those of bare frame. The results show that the strengthened frame by eccentric steel braces applicable in buildings.

Adding concentrically steel braces to the bare frame decreased the story drift, and significantly increased strength, stiffness and energy dissipation capacity.

In this strengthening method lateral load carrying capacity, stiffness and dissipated energy of the structure can be increased.

\section{References}

1. A.Dogan, Research about concentrically steel braced frames according to design specifications for buildings in seismic regions 2007, Master Dissertation; Istanbul Technical University, Istanbul, Turkey (2007)

2. TEC-2007, Turkish Code for the Seismic Design of Structures, (2007)

3. C.D.Annan, M.A. Youssef, M.H. El Naggar, Eng. Struct. 31, 7, (2009)

4. G. Brandonisio, M. Toreno, E Grande, E. Mele, A. De Luca, J. Construct. Steel Res. 78 (2012)

5. E. Grande, A. Rasulo, Eng. Struct. 49 (2013)

6. I. Hajirasouliha, A. Doostan, Adv. Eng. Software 41, 3 (2010)
7. R.A. Jazany, I. Hajirasouliha, H. Farshchi, J. Construct. Steel Res. 88 (2013),

8. G. Metelli, Eng. Struct. 46 (2013)

9. A.E. Ozel, E.M. Guneyisi, Struct. Safety, 33, 1 (2011)

10. C.W. Roeder, E.J. Lumpkin, D.E. Lehman J. Construct. Steel Res., 67, 11 (2011)

11. Maheri, M.R., Kousari, R. and Razazan, M. (2003), "Pushover tests on steel X-braced and knee-braced RC frames", Eng. Struct., 25(13), 1697-1705.

12. Z. Qu, S. Kishiki, Y. Maida, H. Sakata, A. Wada Eng. Struct. 105 (2015)

13. A. Khampanit, S. Leelataviwat, J. Kochanin, P. Warnitchai, Eng. Struct. 81 (2014)

14. T. Görgülü, Y.S. Tama, S. Yilmaz, H. Kaplan, Z. Ay, J. Construct. Steel Res. 70 (2012)

15. TS EN ISO 6892-1st, Metallic materials- Tensile Testing- Part-1: Method of test at room temperature, Turkish Standards Institution, Ankara (2010)

16. SAP2000, version 15, CSI Company, Berkeley, California, USA.

17. SAP2000 User Manual, CSI Company, Berkeley, California (2000)

18. FEMA 273/356, Federal Emergency Management Agency, 1996 a, Guidelines for the Seismic Rehabilitation of Buildings, Redwood City, California, USA (1996)

19. M., Inel, H. B., Ozmen, Struct. Eng. Mech. 30, 5 (2008) 